\title{
Proceeding
}

Supplementary Issue: Summer Conferences of Sports Science. Costa Blanca Sports Science Events, 25-26 September 2020. Alicante, Spain.

\section{Plyometry and room football in the cognitive disability: Text to practice}

\author{
CRISTIAN LEONARDO CEPEDA ${ }^{1} \triangle$, YOFRE DANILO SANABRIA-ARGUELLO², PAULO JONATHAN \\ ACOSTA-TOVA ${ }^{3}$, GLADYS JAIMES-JAIMES ${ }^{2}$ \\ ${ }^{1}$ Santo Tomas Tunja University, Colombia \\ 2Pedagogical and Technological University of Colombia, Colombia \\ 3 Institute of Physical Education Recreation and Sports from Paipa, Colombia
}

\begin{abstract}
The present research was carried out through the application of a plyometric training program for 8 weeks, performing the 3 weekly sessions, in order to determine its influence on the power of the lower body in the athletes of the futsal team Boyacá with diagnosed cognitive disability with borderline mental delay. The intervened population were 10 athletes, with an average age of $20.10 \pm 1.9$ years, average height of 174.10 \pm 9.757 centimetres, average weight of $67.60 \pm 10.178$ kilograms; A study of the participants was carried out demanding the Axon Jump platform and the Carmelo Bosco protocol, a plyometric training program based on ATR planning was designed and applied, and finally the evaluation was reapplied to athletes. It follows that the $p$-Value from the test (bilateral sig.), it presenting value greater than .05 in the three jumps, assuming both equality of the variances and different variances, which induces that the differences between the improvement percentages and the players of the trained group with plyometric emphasis and the control group did not differ significantly in the maximum relation, reactive and explosive power indicators.
\end{abstract}

Keywords: Plyometry; ATR, Power; Indoor soccer; Cognitive disability.

\section{Cite this article as:}

Cepeda, C.L., Sanabria-Arguello, Y.D., Acosta-Tova, P.J., \& Jaimes-Jaimes, G. (2020). Plyometry and room football in the cognitive disability: Text to practice. Journal of Human Sport and Exercise, 15(4proc), S1418S1426. doi:https://doi.org/10.14198//hse.2020.15.Proc4.38

Corresponding author. Santo Tomas Tunja University, Avenida Universitaria 45 - 202, Tunja, Boyacá, Colombia. https://orcid.org/0000-0001-6694-6286

E-mail: cristiancepeda14@gmail.com

Abstract submitted to: Spring Conferences of Sports Science. Costa Blanca Sports Science Events, 19-20 June 2020. Alicante, Spain.

JOURNAL OF HUMAN SPORT \& EXERCISE ISSN 1988-5202

(c) Faculty of Education. University of Alicante

doi:10.14198/jhse.2020.15.Proc4.38

S1418 | 2020| Proc4 | VOLUME 15

(c) 2020 University of Alicante 


\section{INTRODUCTION}

The sport's evolution in terms of technology and training methods have demonstrated a great advance, pretending to be every time more specific in the development from the physical capacities of athletes at any stage of their sports training. In consequence, in the great variety of the individual and collective sport modalities, it is necessary to work on the different conditional capacities such as Force, speed, resistance, flexibility and coordinative ones, taking into account that within it, "force occupies and essential place for any human being, either as a fundamental physical capacity limiting performance, or to guarantee the performance of any motor action" (Siff \& Verkhoshansky,2000). Therefore, the sport modalities require a good development of strength and power in the lower limbs in the train to keep optimal sport performance during competition and enhance the performance of the athletes in different game situations.

On the other hand, Verhoshanski, (1993) affirms that the power as the specific ability to the develop from a high impulse of force immediately after a hard sudden mechanical muscle stretching: that's says, it will be the ability to move quickly from eccentric to concentric muscular work and at the same time there are authors who refers that for the development of this capacity its, "efficacy depends on a series of variables such as: intensity, volume, chosen exercise, rest, movement speed and training frequency among others"( William J. Kraemer,2004).

In agreement, this article is the results from an investigation which was fulfilled to the Boyacá soccer team with cognitive disabilities, where it was applied the plyometric training method based on the ATR planning model, which seeks to accentuate or concentrate loads than would be used in the transformation, taking into account a sum of volume and intensity can be modified according to the sport modality, Agudelo c., (2012). The above was improving the power of the lower body of the athlete belonging to the Boyacá futsal team with cognitive disabilities, so the macrocycle was bases on 3 mesocycles, which in turns consisted of 8 micro cycle, where 3 sessions were carried out per micro cycle, for a total of 24 sessions, the power of the lower body from the athletes under a study was evaluated through the Carmelo's Bosco protocol, using as an instrument in order to get the Axon jump 4.0 platform information. This information was fulfilled working on two moments: before and after the application from the plyometric training program.

In this way, it is necessary to take into account that the plyometric training method will admit the combination of exercises with two phases; one of them is eccentric and one concentric contraction, with the purpose to have a natural incentive for the performance from the athletes, so that performance in vertical jumps is a really important factor in the execution from many movements, taking into account for the ballistic nature from human movement. Today the plyometric method is widely accepted. Taking into account that the most sport gestures get involved concentric contractions after a muscle stretch.

In addition, this research aims to cooperate with the sport processes from the coaches in the different disciplines, in turns, the plyometric training program could be used in individual and group sport, in order to get positive effect on the performance from muscle power during the competitive cycles.

\section{MATERIALS AND METHODS}

The participants from the present study were 10 athletes from Boyacá futsal team with cognitive disabilities with an average age from $20.10 \pm 1.96$ years, average height of $174.10 \pm 9.757$ centimetres, average weight of $67.60 \pm 10.178$ kilograms, which five (5) worked on the plyometric training method with the ATR planning 
model and remaining five (5) athletes were taken as a control group who continued with their traditional training plan in which they worked with diluted loads.

The development of this research was initially through a measurement from the intervened sample, where a diagnosis was made by the Carmelo Bosco protocol, assessing the individual characteristics and the selection of specific qualities for each athlete, analysing three specific jumps through the Axon jump platform such as Squat jump (SJ), Counter movement jump (CMJ) and Abalakob (ABK), after that, the plyometric training program based on the ATR planning model was developed, seeking to stimulate the power of the lower body in the athlete to generate better dexterity and ability within the field of play. At the end, the athletes are evaluated through the same evaluation carried out initially, having as a result the jump height, mechanical power of the jump and use of elastic energy, the data that was got from the heights in different types of vertical jumps were analysed by the statistical software SPSS 25 in order to answer the questions of this research.

The data collection was fulfilled using the Axon Jump 4.0 contact platform. The mat operates a high resolution time (1 msec) that is in the provided program. The heigh and speed from the jumps are calculated by itself, if the jump is technically well executed the precision of the measurements is very high.

\section{RESULTS}

Table 1. Group of characteristics.

\begin{tabular}{ccc} 
Age (years) & Height $(\mathbf{c m})$ & Weight(kg) \\
\hline $20.10 \pm 1.90$ & $174.10 \pm 9.75$ & $67.60 \pm 10.17$
\end{tabular}

Power analysis

Table 2. Power from the subjects and percentage of improvement at individual and group level.

\begin{tabular}{|c|c|c|c|c|c|c|c|c|c|}
\hline \multirow{2}{*}{$\begin{array}{l}\text { Watts } \\
\text { Athlete }\end{array}$} & \multicolumn{3}{|c|}{ ABK } & \multicolumn{3}{|c|}{ CMJ } & \multicolumn{3}{|c|}{ SJ } \\
\hline & $\begin{array}{l}\text { Pre } \\
\text { test }\end{array}$ & $\begin{array}{l}\text { Post } \\
\text { test }\end{array}$ & $\begin{array}{l}\text { \%Individual } \\
\text { improveme } \\
\text { nt }\end{array}$ & $\begin{array}{l}\text { Pre } \\
\text { test }\end{array}$ & $\begin{array}{l}\text { Post } \\
\text { test }\end{array}$ & $\begin{array}{l}\text { \% Individual } \\
\text { improveme } \\
\text { nt }\end{array}$ & $\begin{array}{l}\text { Pre } \\
\text { test }\end{array}$ & $\begin{array}{l}\text { Post } \\
\text { test }\end{array}$ & $\begin{array}{l}\text { \%Individual } \\
\text { improveme } \\
\text { nt }\end{array}$ \\
\hline \multirow{7}{*}{ 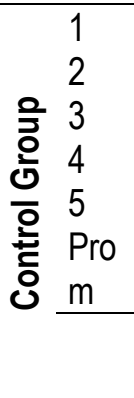 } & 437.1 & 439.5 & 0.5 & 435.7 & 436.3 & 0.1 & 430.7 & 439 & 1.93 \\
\hline & 904.3 & 905.1 & 0.1 & 900 & 901.2 & 0.1 & 898.8 & 899.6 & 0.09 \\
\hline & 1084.4 & 1087.3 & 0.3 & 1077.7 & 1079.6 & 0.2 & 1078.3 & 1080.2 & 0.18 \\
\hline & 465.7 & 462.8 & -0.6 & 463.3 & 465 & 0.4 & 465 & 466.7 & 0.37 \\
\hline & 1258.1 & 1258.1 & 0.0 & 1258.1 & 1257.9 & 0.0 & 1255.9 & 1257.9 & 0.16 \\
\hline & 829.9 & 830.6 & 0.1 & 827.0 & 828.0 & 0.2 & 825.7 & 828.7 & 0.5 \\
\hline & \multicolumn{2}{|c|}{$\begin{array}{l}\text { \%Group } \\
\text { Improvement }\end{array}$} & 0.1 & \multicolumn{2}{|c|}{$\begin{array}{l}\text { \%Group } \\
\text { Improvement }\end{array}$} & 0.1 & \multicolumn{2}{|c|}{$\begin{array}{l}\text { \%Group } \\
\text { Improvement }\end{array}$} & 0.4 \\
\hline \multirow{7}{*}{ 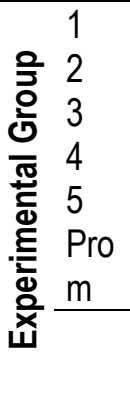 } & 527.1 & 530.1 & 0.6 & 520.4 & 521.2 & 0.2 & 518.5 & 520.3 & 0.15 \\
\hline & 615.7 & 617.3 & 0.3 & 612 & 613.2 & 0.2 & 611.6 & 614.3 & 0.20 \\
\hline & 610.7 & 613.2 & 0.4 & 606.4 & 609.9 & 0.6 & 606.6 & 609.5 & 0.58 \\
\hline & 611.6 & 614.3 & 0.4 & 610.3 & 612 & 0.3 & 612.1 & 612.7 & 0.28 \\
\hline & 358.9 & 358 & -0.3 & 356.9 & 357.7 & 0.2 & 356.5 & 357.7 & 0.22 \\
\hline & 544.8 & 546.6 & 0.3 & 541.2 & 542.8 & 0.3 & 541.1 & 542.9 & 0.3 \\
\hline & \multicolumn{2}{|c|}{$\begin{array}{l}\text { \%Group } \\
\text { Improvement }\end{array}$} & 0.3 & \multicolumn{2}{|c|}{$\begin{array}{l}\text { \%Group } \\
\text { Improvement }\end{array}$} & 0.3 & \multicolumn{2}{|c|}{$\begin{array}{l}\text { \%Group } \\
\text { Improvement }\end{array}$} & 0.3 \\
\hline
\end{tabular}


The interceded population were 10 athletes with an average age from $20.10 \pm 1.9$ years, average height of $174.10 \pm 9.757$ centimetres, average weight of $67.60 \pm 10.178$ kilograms.

Regarding the control group, it is observed that in $\mathrm{ABK}=0.1 \% ; \mathrm{CMJ}=0.1 \%$ and $\mathrm{SJ}=0.4 \%$ in the percentage of group improvement, while the experimental group $\mathrm{ABK}=0.3 \%$; $\mathrm{CMJ}=0.3 \%$ and $\mathrm{SJ}=0.3 \%$. This being an indication of constant improvement in the experimental group, however the control group obtained the greatest improvement reflected in the SJ jump. Thus, evidencing that the athletes of this group improved the capacity of nervous recruitment and therefore, the percentage of fast fibres at the time of execution of the jumps in a higher percentage.

Table 3. KS normality test control group.

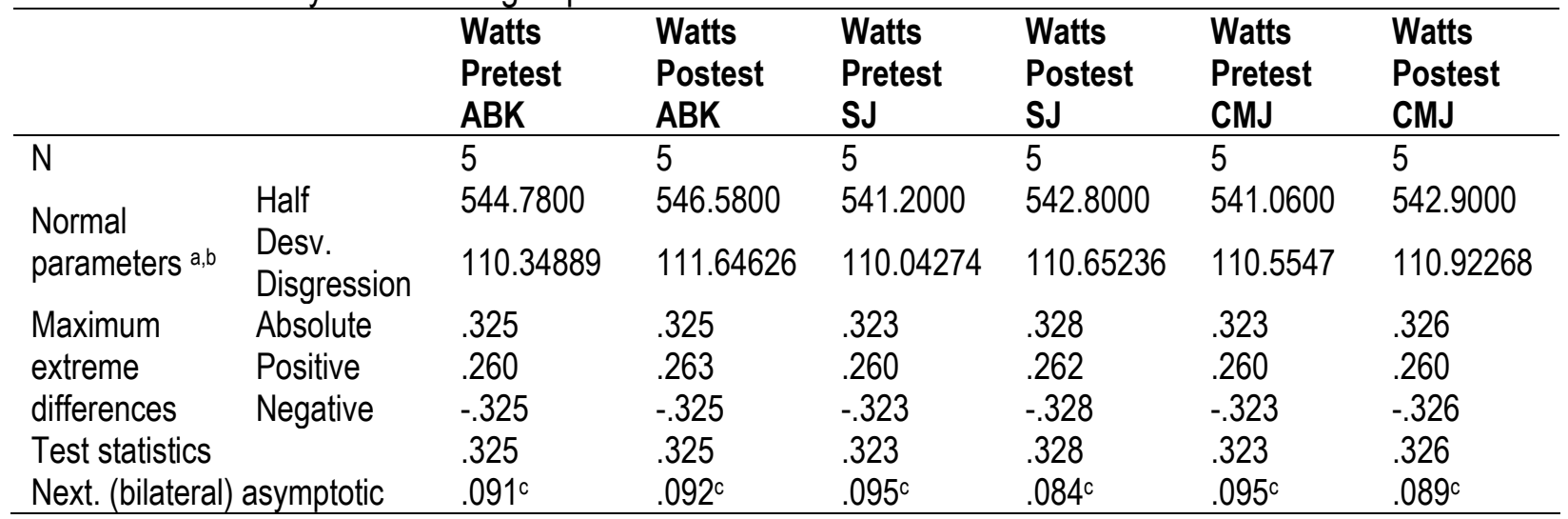

a. The test distribution is normal. b. Its calculated from data. c. Lilliefors significance correction.

Table 4. KS normality test experimental group.

\begin{tabular}{|c|c|c|c|c|c|c|c|}
\hline & & $\begin{array}{l}\text { Watts } \\
\text { Pretest } \\
\text { ABK }\end{array}$ & $\begin{array}{l}\text { Watts } \\
\text { Postest } \\
\text { ABK }\end{array}$ & $\begin{array}{l}\text { Watts } \\
\text { Pretest } \\
\text { SJ }\end{array}$ & $\begin{array}{l}\text { Watts } \\
\text { Postest } \\
\text { SJ }\end{array}$ & $\begin{array}{l}\text { Watts } \\
\text { Pretest } \\
\text { CMJ }\end{array}$ & $\begin{array}{l}\text { Watts } \\
\text { Postest } \\
\text { CMJ }\end{array}$ \\
\hline \multicolumn{2}{|l|}{$\mathrm{N}$} & 5 & 5 & 5 & 5 & 5 & 5 \\
\hline \multirow{2}{*}{$\begin{array}{l}\text { Normal } \\
\text { parameters a,b }\end{array}$} & Half & 829.9200 & 830.5600 & 826.9600 & 828.0000 & 825.7400 & 828.6800 \\
\hline & $\begin{array}{l}\text { Desv. } \\
\text { Disgression }\end{array}$ & 367.62560 & 368.25176 & 367.22611 & 366.97163 & 367.54316 & 365.85577 \\
\hline Maximum & Absolute & .239 & .241 & .239 & .239 & .237 & .239 \\
\hline extreme & Positive & .239 & .241 & .239 & .239 & .237 & .239 \\
\hline differences & Negative & -.180 & -.180 & -.179 & -.179 & -.179 & -.177 \\
\hline Test statistics & & & .241 & .239 & .239 & .237 & .239 \\
\hline Next. (bilateral) & asymptotic & & $.200^{\mathrm{c}, \mathrm{d}}$ & $200^{c, d}$ & $.200^{\mathrm{c}, \mathrm{d}}$ & $.200^{c, d}$ & $.200^{c, d}$ \\
\hline
\end{tabular}

Table 5. Paired sample correlations control group.

\begin{tabular}{llccc}
\hline & & N & Correlation & Sig. \\
\hline Par 1 & Pot.Pre.ABK \& Pot.Post.ABK & 5 & 1.000 & .000 \\
Par 2 & Pot.Pre.SJ \& Pot.Post.SJ & 5 & 1.000 & .000 \\
Par 3 & Pot.Pre.CMJ \& Pot.Post.CMJ & 5 & 1.000 & .000 \\
\hline
\end{tabular}


The normality tests in tables 3 and 4 indicate that the data of the watts in the ABK-SJ and CMJ jump's, both in the pretest and in the posttest and the improvement percentages in each of them are normal, since the $P$ value $($ Sig $)>.05$.

Table 6. Paired sample correlations experimental group.

\begin{tabular}{llccc}
\hline & & N & Correlation & Sig. \\
\hline Par 1 & Pot.Pre.ABK \& Pot.Post.ABK & 5 & 1.000 & .000 \\
Par 2 & Pot.Pre.SJ \& Pot.Post.SJ & 5 & 1.000 & .000 \\
Par 3 & Pot.Pre.CMJ \& Pot.Post.CMJ & 5 & 1.000 & .000 \\
\hline
\end{tabular}

Correlations and significance are evidenced in the jumps of the two groups according to table 5 and 6 . Due to the fulfilment of the normality assumptions.

Table 7. Paired Samples test.

\begin{tabular}{|c|c|c|c|c|c|c|c|c|c|c|}
\hline & & & & Sam & s differen & & & & & \\
\hline & & & Half & $\begin{array}{l}\text { Desv. } \\
\text { Disgression }\end{array}$ & $\begin{array}{l}\text { Desv. } \\
\text { Average }\end{array}$ & $\begin{array}{l}95 \% \text { Conf } \\
\text { Interval of } \\
\text { difference }\end{array}$ & $\begin{array}{l}\text { lence } \\
\text { he }\end{array}$ & $t$ & df & $\begin{array}{l}\text { Next. } \\
\text { (bilateral) }\end{array}$ \\
\hline & & & & & & Inferior & Greater & & & \\
\hline $\begin{array}{l}\text { Par } \\
1\end{array}$ & $\begin{array}{l}\text { Pot.Pre.ABK } \\
\text { Pot.Post.ABK }\end{array}$ & - & -1.80000 & 1.60624 & .71833 & -3.79441 & 19441 & -2.506 & 4 & .066 \\
\hline $\begin{array}{l}\text { Par } \\
2\end{array}$ & $\begin{array}{l}\text { Pot.Pre.SJ } \\
\text { Pot.Post.SJ }\end{array}$ & - & -1.60000 & 1.12472 & .50299 & -2.99653 & -.20347 & -3.181 & 4 & .034 \\
\hline $\begin{array}{l}\text { Par } \\
3\end{array}$ & $\begin{array}{l}\text { Pot.Pre.CMJ } \\
\text { Pot.Post.CMJ }\end{array}$ & - & -1.84000 & .97622 & .43658 & -3.05213 & -.62787 & -4.215 & 4 & .014 \\
\hline
\end{tabular}

Table 8. Paired simples test.

\begin{tabular}{|c|c|c|c|c|c|c|c|c|c|c|}
\hline & & & \multicolumn{5}{|c|}{ Samples differences } & \multirow{3}{*}{$\mathbf{t}$} & \multirow{3}{*}{ df } & \multirow{3}{*}{$\begin{array}{l}\text { Next. } \\
\text { (bilateral) }\end{array}$} \\
\hline & & & \multirow[t]{2}{*}{ Half } & \multirow[t]{2}{*}{$\begin{array}{l}\text { Desv. } \\
\text { Disgression }\end{array}$} & \multirow{2}{*}{$\begin{array}{l}\text { Desv. } \\
\text { Average } \\
\text { Error }\end{array}$} & \multicolumn{2}{|c|}{$\begin{array}{l}95 \% \text { Confidence } \\
\text { Interval of the } \\
\text { difference }\end{array}$} & & & \\
\hline & & & & & & Inferior & Greater & & & \\
\hline Par 1 & $\begin{array}{l}\text { Pot.Pre.ABK } \\
\text { Pot.Post.ABK }\end{array}$ & & -0.64 & 2.30065 & 1.02888 & -3.49664 & 2.21664 & -0.622 & 4 & 0.568 \\
\hline Par 2 & $\begin{array}{l}\text { Pot.Pre.SJ } \\
\text { Pot.Post.SJ }\end{array}$ & - & -1.04 & 0.85615 & 0.38288 & -2.10306 & 0.02306 & -2.716 & 4 & 0.053 \\
\hline Par 3 & $\begin{array}{l}\text { Pot.Pre.CMJ } \\
\text { Pot.Post.CMJ }\end{array}$ & - & -2.94 & 3.03364 & 1.35669 & -6.70677 & 0.82677 & -2.167 & 4 & 0.096 \\
\hline
\end{tabular}

Table 9. Percentage improvement from control group and experimental group.

\begin{tabular}{ccccccc}
\hline & \multicolumn{2}{c}{ Abalakov \% Improvement } & \multicolumn{2}{c}{ Countermovement \% Improvement } & \multicolumn{2}{c}{ Squat Jump \% Improvement } \\
\hline \multirow{2}{*}{ Athlete } & $\begin{array}{c}\text { Control } \\
\text { Group }\end{array}$ & $\begin{array}{c}\text { Experimental } \\
\text { Group }\end{array}$ & $\begin{array}{c}\text { Control } \\
\text { Group }\end{array}$ & $\begin{array}{c}\text { Experimental } \\
\text { Group }\end{array}$ & $\begin{array}{c}\text { Control } \\
\text { Group }\end{array}$ & $\begin{array}{c}\text { Experimental } \\
\text { Group }\end{array}$ \\
\hline 1 & 0.55 & 0.57 & 0.14 & 0.15 & 1.93 & 0.15 \\
2 & 0.09 & 0.26 & 0.13 & 0.2 & 0.09 & 0.2 \\
3 & 0.27 & 0.41 & 0.18 & 0.58 & 0.18 & 0.58 \\
4 & -0.62 & 0.44 & 0.37 & 0.28 & 0.37 & 0.28 \\
5 & 0 & -0.25 & -0.02 & 0.22 & 0.16 & 0.22 \\
PROM & 0.06 & 0.29 & 0.16 & 0.29 & 0.54 & 0.29 \\
\hline
\end{tabular}


The t-student test was performed with a significance level $a=.05$. If the significance is greater than 0.05 it indicates that the differences in Watts are not significant in the average of the two jumps, and if it is less than 0.05 it indicates that the differences in Watts are significant on average.

From Table 10 it can be deduced that the improvement percentages for the experimental group was constant $=0.29$ in the three jumps, while the control group $\mathrm{ABK}=0.06 ; \mathrm{CMJ}=0.16$ and $\mathrm{SJ}=0.54$.

Table 10. Student's t-test for independent samples.

\begin{tabular}{|c|c|c|c|c|c|c|c|c|c|c|}
\hline & & \multicolumn{2}{|c|}{$\begin{array}{l}\text { Levene test of } \\
\text { equality of } \\
\text { variances }\end{array}$} & \multicolumn{7}{|c|}{$T$ test for equality of means } \\
\hline & & \multirow[t]{2}{*}{$\mathrm{F}$} & \multirow[t]{2}{*}{ Sig. } & \multirow[t]{2}{*}{$t$} & \multirow[t]{2}{*}{ df } & \multirow[t]{2}{*}{$\begin{array}{l}\text { Next. } \\
\text { (bilateral) }\end{array}$} & \multirow[t]{2}{*}{$\begin{array}{l}\text { Mean } \\
\text { difference }\end{array}$} & \multirow[t]{2}{*}{$\begin{array}{l}\text { Standard } \\
\text { error } \\
\text { difference }\end{array}$} & \multicolumn{2}{|c|}{$\begin{array}{l}95 \% \text { Confidence } \\
\text { Interval of the } \\
\text { difference }\end{array}$} \\
\hline & & & & & & & & & Inferior & Greater \\
\hline \multirow{2}{*}{$\begin{array}{l}\text { Improvement. } \\
\text { ABK }\end{array}$} & $\begin{array}{l}\text { Equal variances } \\
\text { are assumed }\end{array}$ & 0.132 & 0.726 & 0.914 & 8 & 0.388 & 0.22 & 0.24083 & -0.33536 & 0.77536 \\
\hline & $\begin{array}{l}\text { Equal variances } \\
\text { are not assumed }\end{array}$ & & & 0.914 & 7.712 & 0.389 & 0.22 & 0.24083 & -0.33898 & 0.77898 \\
\hline \multirow{2}{*}{$\begin{array}{l}\text { Improvement. } \\
\text { SJ }\end{array}$} & $\begin{array}{l}\text { Equal variances } \\
\text { are assumed }\end{array}$ & 0.017 & 0.901 & 1.36 & 8 & 0.211 & 0.14 & 0.10296 & -0.09742 & 0.37742 \\
\hline & $\begin{array}{l}\text { Equal variances } \\
\text { are not assumed }\end{array}$ & & & 1.36 & 7.863 & 0.212 & 0.14 & 0.10296 & -0.09814 & 0.37814 \\
\hline \multirow{2}{*}{$\begin{array}{l}\text { Improvement. } \\
\mathrm{CMJ}\end{array}$} & $\begin{array}{l}\text { Equal variances } \\
\text { are assumed }\end{array}$ & 4.403 & 0.069 & -0.574 & 8 & 0.582 & -0.204 & 0.35529 & -1.0233 & 0.6153 \\
\hline & $\begin{array}{l}\text { Equal variances } \\
\text { are not assumed }\end{array}$ & & & -0.574 & 4.286 & 0.595 & -0.204 & 0.35529 & -1.16501 & 0.75701 \\
\hline
\end{tabular}

From Table 10 it can be deduced that the P-value of the test (Bilateral Sig.) Presents values higher than 0.05 in the three jumps and it can be concluded that the differences between the improvement percentages between the players in the group that trained with Plyometric method and those of the control group, do not differ significantly in relation to the maximum, reactive and explosive indicators of power.

\section{DISCUSSION}

For the proposed variable of power, it is recorded that there were significant improvement changes after the application from the plyometric training program based on the ATR planning model. Also, it follows that this method of muscular work is essential for the development of large force impulses in short periods of time (Verkhoshansky, 2000). Otherwise, The percentages of jumping height are among the recommended quantifications for power training in regard to plyometrics, (Cappa, 2000) states that "to calculate the power in watts of the jumps there are validated formulas that relate jump height and weight", as is the formula proposed by Harman cited by (Acero, 2009) to calculate power indirectly. As for the ATR parameters, they are similar to those provided by (Sanabria, 2013) and also (Agudelo VC, 2019) in the article where they state that for the ATR micro cycles the load accentuations are considered more relevant to improve a capacity specify in a short time.

The main result of the present stud are showing really important difference compared to the investigations proposed by Wilson et al (1993), in which they didn't find significant increases I peak power after 10 weeks plyometric training. Approximately, after 2 sessions per week. Therefore, Flarity et al (1997) didn't find significant improvement in peak power and average power after plyometric training. This study lasted 9 wells performing 3 session per week. However, Diallo et al (2001), also with a training lasting 10 weeks applying 
3 sessions per week, where it was obtained a significant improvement in peak power. It could be noted that in these last two commented studies (Wilson et al., 1993; Diallo et al., 2001) a variant of the 10-second Wingate test was used, only aimed at quantifying peak power.

Taking into account, the results of the present research it could be seen the application from a plyometric training program from the Boyacá futsal team with cognitive disabilities generated a difference in the improvement percentage of the experimental group greater than the improvement percentages of the control group, only in the $A B K$ and CMJ jumps, while, the SJ jump the percentage of improvement is better in the control group than in the experimental group without their differences being statistically significant.

\section{CONCLUSIONS}

Taking into account the results its evident that there were improvements in the maximum and explosive power from the experimental group which fulfilled training with the plyometric method, where allows us to deduce the work of the concentric.

For the experimental group, the jumps that exhibited the highest percentage of improvement was the SJ, this proofing that the athletes improved the capacity of nervous recruitment and at the same time, the percentage of fast fibres at the moment of execution from the jumps. In the same manner of the CMJ, where they used the elastic energy gathered in the quadriceps at the moment of flexion extension and taking the push for the jump.

The scant significance in the improvement from the power of the lower body in the experimental group in connection to the control group may be due to the short time of application from the program from what its recommended for future research, the time of work with exercises plyometrics is longer lasting.

The plyometric training can be used as a means to improve the lower body, not only in futsal, but also in other sports.

\section{REFERENCES}

Acosta, P., Sanabria, Y; Agudelo, C. (2016). Comparación del efecto de los métodos continuo e intermitente en el desarrollo de la resistencia aerobica en jugadoras de fútbol. Actividad fisica y desarrollo humano, 16-24 (7). ISSN 1692-7427.

Acero, J. (2009). Aplicaciones de la Biomecánica Deportiva en los procesos de Entrenamiento Deportivo. Instituto Universitario de Educación Física. Universidad de antioquia., Medellin.

Agudelo, C. (2012). Planificacion del entrenamiento deportivo por modelamiento. Armenia : Kinesis.

Agudelo, V. C. (2019). El modelo ATR como sistema alternativo de entrenamiento e investigación en el deporte. Revista de educacion fisica, 8(1).

Aranda, I. (2014). Analisis de las acciones ofensivas que concluyen en gol de la liga nacional de futbol sala (LNFS) durante la temporada 2013 - 2014. Facultad de ciencias de la salud y del deporte Huesca Universidad Zaragoza.

Axon Bioingenieria Deportiva. (Accesed 09/28/2019). Retrieved from: https://www.axonjump.com.ar/

Bompa, T. (2003). Entrenamiento de la Potencia para el Fútbol. PubliCE Standard.

Bosco, C. (1994). La valoración de la fuerza con el test de Bosco. Coleccion deporte y entrenamiento, $25-46$.

Cappa, D. (2000). Entrenamiento de la Potencia Muscular. Grupo Sobre entrenamiento (primera ed.). 
Cepeda, C., Gamboa, F., \& Sanabria, Y. (2019). Antecedentes, descripción, potencia del tren inferior y pliometría en fútbol sala. Actividad fisica y deporte. 6 (1): 165-178.

Chu, D. A. (1993). Ejercicios pliometricos. Barcelona: Paidotribo.

Corzo, A. H. (2005). Teoría del Entrenamiento Pliométrico. Journal Publice. Retrieved from: https://gse.com/teoria-del-entrenamiento-pliometrico-578-sa-s57cfb27162e0f

Croin, J., \& Sleivert, G. (2005). Challenges in understanding the influence of maximal power training on imporving athletic performance. Sports Medicine, 213-234. https://doi.org/10.2165/00007256200535030-00003

Diallo, O., Dore, E., Duche, P., \& Van Praagh, E. (2001). Effects of plyometric training followed by a reduced training programme on physical performance in prepubescent soccer players. Sports Med Phys Fitness, 41(3), 342-348.

Elisa Benito Martínez, L. S.-L. (2010). Efecto del entrenamiento combinado de pliometría y electroestimulación en salto vertical. (Effect of combined plyometric and electrostimulation training on vertical jump). RICYDE, 13. https://doi.org/10.5232/ricyde2010.02106

Garcia Lopez, D. H. (2003). Metodologia del entrenamiento pliometrico. Revista internacionalde medicina y ciencias de la actividad fisica y el deporte, 14 .

González Badillo, J. J. (2000). Concepto y medida de la fuerza explosiva en el deporte. Posibles aplicaciones al entrenamiento. Revista de Entrenamiento Deportivo, 5-16.

Gutierrez, F. G. (2010). Concepto y clasificacion de las capacidades fisicas. Resvista de investigacion cuerpo, cultura y movimientos, 1(1), 77-86. https://doi.org/10.15332/s2248-4418.2011.0001.04

Hermassi, S., Gabbett, T., Ingebrigtsen, J., van den Tillaar, R., Chelly, M., \& Chamari, K. (2014). Effects of a Short-Term In-Season Plyometric Training Program on Repeated-Sprint Ability, Leg Power and Jump Performance of Elite Handball Players. International Journal of Sports Science and Coaching., 1205-1216. https://doi.org/10.1260/1747-9541.9.5.1205

Herzon, W., \& Ait-Haddou, R. (2002). Considerations on muscle contraction. Electromyougr; Kinesiol, 425-433. https://doi.org/10.1016/S1050-6411(02)00036-6

Miller, M. G., Herniman, J. J., Ricard, M. D., Cheatham, C. C., \& Michael, T. J. (2016). Efectos de un Programa de Entrenamiento Pliométrico de Seis Semanas sobre la Agilidad. Sports Science \& Medicine. OMS. (2001). Clasificación Intenacional del funcionamiento de la capacidad y de la salud. Ginebra.

Ortiz, R. R. (2004). Tenis: Potencia, Velocidad y movilidad. En O. R. Horacio, Tenis: Potencia, Velocidad y movilidad (pág. 272). España: INDE.

Roman, S. I. (2004). Giga Fuerza. La habana: Deportes.

Salalazar, L. J. (2016). Guía de ejercicios pliométricos para el desarrollo de la fuerza explosiva de los jugadores de futbol sala de la categoría 18 años del club "Pupilos de Oro" del cantón Daule. Guayaquil Ecuador.

Sanabria, Y. D, \& Agudelo, C. A. (2011). Programa de preparación física en velocidad de desplazamiento en el fútbol sala. Revista educación física y deporte. Vol. 30-2 p. 629-635.

Sanabria-Arguello, Y.D., Agudelo-Velasquez, C.A., \& Callejas-Cuervo, M. (2020). Practical analysis of power in professional footballers. Journal of Human Sport and Exercise, 15(3proc), S763-S769. https://doi.org/10.14198/ihse.2020.15.Proc3.26

Sánchez, A., \& Floría, P. (2017). efecto del entrenamoento combinado de fuerza y pliometría en variables biomecánicas del salto verticalen jugadoras de baloncesto. Retos(31).

Siff, M., \& Verkhoshansky, Y. (2000). Supertentrenamiento. España: Paidotribo.

Valero, D. V., \& Suarez, M. J. (2018). Analisis de la evaluacion de potencia en tren inferior: Una revision sistematica. Actividad fisica y deporte , 33. 
Vallodoro, E. (2008). La fuerza resistencia. Retrieved from: Entrenamiento Deportivo at https://entrenamientodeportivo.wordpress.com/2008/12/08/la-fuerza-resistencial

Verhoshanski, Y. \&. (1993). Speed-strength preparation of future champions. Soviet Sports Review, 166170.

Verkhoshansky, Y. (2000). Todo sobre el método pliométrico para el entrenamiento y la mejora de la fuerza. Barcelona: Paidotribo.

\section{(C) (i) (9)}

This work is licensed under a Attribution-NonCommercial-NoDerivatives 4.0 International (CC BY-NC-ND 4.0). 